\title{
Surface characteristics and optical properties of plasma deposited films on indirect aesthetic restorative dental materials ${ }^{\text {it }}$
}

\author{
Mariana Cavalcante dos Reis ${ }^{\mathrm{a}, *}$, Vilmara Rocha Mendes Silva ${ }^{\mathrm{a}}$, Ricardo Sgura ${ }^{\mathrm{b}}$, \\ Nilson Cristino da $\mathrm{Cruz}^{c}$, Elidiane Cipriano Rangel ${ }^{c}$, Igor Studart Medeiros ${ }^{\mathrm{a}}$ \\ a Department of Biomaterials and Oral Biology, School of Dentistry, University of São Paulo, Av. Prof. Lineu Prestes, 2227, Cidade Universitária, São Paulo, SP 05508- \\ ooo, Brazil \\ b Dental Materials Course, School of Dentistry, University Nove de Julho, UNINOVE, Rua Vergueiro, 235/249, Liberdade, São Paulo, SP 01504-000, Brazil \\ ${ }^{\mathrm{c}}$ Technological Plasmas Laboratory, Paulista State University, Experimental Campus of Sorocaba Av. Três de Março, 511, Alto da Boa Vista, Sorocaba, São Paulo 18087- \\ 180, Brazil
}

A R T I C L E I N F O

\section{Keywords:}

Thin films

Dental materials

Resin composites

Ceramics

HMDSO

\begin{abstract}
A B S T R A C T
The aim of this study was to develop and characterize wettability, morphology, chemical composition and color of plasma-deposited thin films on the surface of dental materials. A porcelain (VM9, VITA (PC)) and two indirect composite discs (Enamic, VITA (EN) and Lava Ultimate, 3M ESPE (LU)) were used. Different methodologies of film deposition were established: plasma-enhanced chemical vapor deposition (PECVD) with HMDSO/Ar (PAr); PECVD with HMDSO/O $\mathrm{O}_{2}\left(\mathrm{PO}_{2}\right)$; plasma immersion ion implantation and deposition using HMDSO/Ar (PII). Surface roughness and film thickness were determined by profilometry. Contact angles were measured with a goniometer. Morphological analysis was evaluated using SEM and chemical composition was investigated by FTIR and XPS. Color differences $(\Delta \mathrm{E})$ were verified by a spectrophotometer. The films' thicknesses were $620 \mathrm{~nm}$ (PAr), $540 \mathrm{~nm}\left(\mathrm{PO}_{2}\right)$ and $70 \mathrm{~nm}$ (PII). Surface roughness was not changed for most of the groups. An increase in contact angles for all film groups was detected, except for LU-PII group. In $\mathrm{PO}_{2}$ films, granular structures covered the entire surface and their presence decreased in PAr and PII. Color differences maintained below 3.0. $\mathrm{PO}_{2}$ showed a silica-like and PII silicon oxycarbide-like structure and PAr presented an organic behavior. Plasmadeposited thin films were developed and altered surface characteristics of restorative materials, maintaining the materials color and adequate surface roughness potentially working as a protective barrier.
\end{abstract}

\section{Introduction}

Aesthetic dental materials such as resin composites and ceramics are the two most widely used materials in dental practice. Ceramics have excellent biocompatibility, chemical inertness, good color stability, low thermal conductivity and wear resistance [1-4]. Resin composites also present various qualities like excellent aesthetic, good biocompatibility [5], intermediate strength between porcelain and crystalline ceramics, lower cost and they are easier to repair, when compared to ceramics $[5,6]$.

The oral cavity is a complex environment with unique conditions that cause deleterious effects to restorative materials. It involves elements such as saliva, containing primarily water and different types of enzymes and bacteria $[7,8]$, temperature variation, which could augment the kinetics of the reactions between the fluids and restorative materials, as well as $\mathrm{pH}$ variations [9]. Combined to all those factors there are also the presence of stresses, masticatory and related to thermal expansion mismatches between the various components of the restoration [10-12]. The exposure of these materials to an aqueous ambient has been found to affect different properties of ceramics and resin composites and decrease their longevity as restorations [13,14].

Strategies to prevent or minimize the degradation of these restorative materials include microstructural modifications or cover layers as chemical/mechanical protection. Rosa et al. [15], showed that ion exchange, substituting smaller sodium atoms for larger potassium ions in the porcelains outer layer, could reduce the material susceptibility to fracture, creating a thin compressive layer in the veneer. Ornaghi et al. [11] showed the development of resin composites with improved formulations, verifying the influence of different filler distributions on subcritical crack growth (SCG) susceptibility, Weibull

\footnotetext{
Declaration of interest: none.

* Corresponding author.

E-mail addresses: marianacavalcantereis@gmail.com (M.C.d. Reis), nilson@sorocaba.unesp.br (N.C.d. Cruz), elidiane@sorocaba.unesp.br (E.C. Rangel), igorsm@usp.br (I.S. Medeiros).
} 
parameters and longevity of the material by dynamic fatigue testing, which demonstrated that different filler sizes affects the materials reliability to bulk fractures.

Another purpose to protect restorative materials includes coatings that function as physical barriers. Silanes used or sol-gel techniques to produce thin films can improve surface and physical properties of ceramics and acrylic resin base materials $[16,17]$. A study showed that organic inorganic hybrid coatings can effectively reduce the water absorption and solubility of a resin [18]. According to these findings, the coatings could decrease water sorption and solubility of the denture base resins by masking the defects on the surface while occluding the micropores and fissures present in the material due to polymerization $[18,19]$.

Plasma-deposited thin films are used to produce coatings on different substrates, that can function as a barrier and protect substrates, such as polyamide [20], metals [21] and ceramics [22], from degradation or corrosion, by two well-known techniques plasma-enhanced chemical vapor deposition [20,23,24] and Plasma Immersion Ion Implantation and Deposition [25]. In dentistry, studies showed the use of plasma techniques to immobilize bioactive molecules on the surfaces of bioinert materials [26], for enhancing adhesive qualities in autopolymerized acrylic resin and lithium disilicate ceramic [27,28] and to modify surfaces like titanium and increase protein-adsorption [26], along with others. Within several possible monomers that can be used as a precursor for plasma techniques and the development of thin films, hexamethyldisiloxane (HMDSO), a organosilicon monomer, shows unique potential for this application [29]. This monomer presents high deposition rates, the flexibility to control the resulting coating structure and properties, by varying the deposition conditions, has a reasonably low cost, produces transparent films in visible spectrum and is relatively nontoxic $[20,26,29]$. The use of plasma-deposited thin films with HMDSO is a focus of continuous research, yet there is none that has been published in order to create a protective barrier on ceramics and resin composites against the many deleterious effects of the oral environment.

Therefore, the purpose of this study was to develop and investigate the influence of different thin films, produced by plasma techniques on surface properties, as well as chemical and optical properties of indirect restorative materials for protective effect. The hypotheses of this study were that (i) the surface properties, such as roughness and optical properties, would not be altered by the presence of the thin films and (ii) wettability, surface morphology and chemical composition of the surfaces would be altered by the presence of the thin films.

\section{Material and method}

\subsection{Specimen preparation}

Thirty-two (32) discs for each material and coating type were prepared (final dimensions of $12.0 \mathrm{~mm}$ in diameter $\times 1.1 \mathrm{~mm}$ in thickness). The materials used in the present study are listed in Table 1.

The porcelain VM9 discs (VITA Zahnfabrik) were produced by the "compression" technique of water suspension in porcelain powder on a polymeric device. The green specimens were sintered according to the thermal cycle, indicated by the manufacturer (Kerampress, Kota, Sao Paulo, Brazil). The CAD/CAM blocks $(17.5 \mathrm{~mm} \times 14 \mathrm{~mm} \times 12 \mathrm{~mm})$ were rounded with a lathe machine and sectioned with a water-cooled diamond saw in a precision cutting machine (Isomet 1000, Buehler, Lake Bluff, USA).

All specimens were leveled with a diamond-grinding disc $(15 \mu \mathrm{m})$ (Buehler, Lake Buff, USA) and mirror polished with a diamond suspension of $15 \mu \mathrm{m}$ (Ecomet 3, Buehler, Lake Buff, USA). After, porcelain specimens were glazed according to the recommendations of the manufacturer.

Specimens were sonically cleaned to remove debris in distilled water with detergent $(100 \mathrm{ml}$ water $+0.12 \mathrm{~g}$ of detergent powder DET LIMP S32, Chemco, Hortolândia, Brazil) for $8 \mathrm{~min}$. After extensive rinsing in running water, samples were washed with only distilled water for another $8 \mathrm{~min}$ and then in isopropyl alcohol for 8 more minutes. Finally, they were dried with the aid of a heat gun (Steinel HL 1500).

\subsection{Plasma treatments}

For film deposition, a tailor made glass vacuum chamber with two parallel plate electrodes was used and evacuated to a background pressure of $2.0 \mathrm{~Pa}$, as shown in a previous study [21]. The gases and vapors were admitted and the plasma was established by the application of radio frequency (Tokyo Hy-Power) signal (13.56 MHz, 50$150 \mathrm{~W}$ ). The depositions were performed at a working pressure of 20 and $24 \mathrm{~Pa}$, according to the deposition parameters of each specific group.

Three different thin films were developed with the following parameters: 1) plasma-enhanced chemical vapor deposition from HMDSO diluted in argon (PAr); 2) plasma-enhanced chemical vapor deposition with HMDSO diluted in oxygen $\left(\mathrm{PO}_{2}\right)$ and 3 ) plasma immersion ion implantation and deposition in HMDSO and argon atmospheres (PII). All gas and vapor mixtures were fixed at a proportion of $30 \%$ of HMDSO and the remaining $70 \%$ was composed of mixtures of oxygen or argon. Deposition time was fixed in $30 \mathrm{~min}$ for the plasma-enhanced chemical vapor deposition technique and $10 \mathrm{~min}$ for the plasma immersion ion implantation and deposition technique. For the PII group, a post-deposition treatment was performed, without exposing samples to air, in pure argon atmosphere (10 $\mathrm{min})$, in order to change the structure of the polymer thin film and improve adhesive properties. All parameters were established based on previous studies $[20,30]$ and after pilot tests. The specimens were divided in four experimental groups for each material, three plasma groups as described previously, and a group with no treatment (CTL), totaling 12 groups.

Table 1

Restorative dental materials used in the study.

\begin{tabular}{|c|c|c|c|c|c|c|}
\hline Material & Abbreviation & Manufacturer & Type & Color & Lote no & Composition \\
\hline Porcelain & $\mathrm{PC}$ & $\begin{array}{l}\text { VITA } \\
\text { Zahnfabrik }\end{array}$ & $\begin{array}{l}\text { Feldspatic Porcelain } \\
\text { (VM9) }\end{array}$ & $2 \mathrm{M} 2$ & $\begin{array}{l}50930 \\
53740 \\
12570 \\
22410\end{array}$ & $\begin{array}{l}\mathrm{SiO}_{2}(60-64 \%), \mathrm{Al}_{2} \mathrm{O}_{3}(13-15 \%), \mathrm{K}_{2} \mathrm{O}(7-10 \%), \mathrm{Na}_{2} \mathrm{O}(4-6 \%), \mathrm{TiO}_{2}(<0.5 \%), \\
\mathrm{CeO}_{2}(<0.5 \%), \mathrm{ZrO}_{2}(0-1), \mathrm{CaO}(1-2 \%), \mathrm{B}_{2} \mathrm{O}_{3}(3-5 \%), \mathrm{BaO}(1-3 \%), \mathrm{S}_{\mathrm{n}} \mathrm{O}_{2} \\
(<0.5 \%), \mathrm{Mg}-, \mathrm{Fe}-, \mathrm{P}-\mathrm{Ox}(<0.1 \%) .\end{array}$ \\
\hline Lava Ultimate & LU & 3M ESPE & Resin nano ceramic & A2LT & $\begin{array}{l}1528000375 \\
1528000373\end{array}$ & $\begin{array}{l}80 \% \text { inorganic, } 20 \% \text { organic (volume). Silica ( } 20 \mathrm{~nm} \text { diameter) and zirconia } \\
\text { nanoparticles ( } 4 \text { to } 11 \mathrm{~nm} \text { ); UDMA, BisGMA and Polyethylene Glycol diether } \\
\text { bisphenol A dimethacrylate ( } 1-10 \% \text { each); Polyethylene glycol dimethacrylate } \\
\text { and TEGDMA }(<5 \%) \text {. }\end{array}$ \\
\hline Enamic & EN & $\begin{array}{l}\text { VITA } \\
\text { Zahnfabrik }\end{array}$ & $\begin{array}{l}\text { Hybrid nano ceramic } \\
\text { (PICN - Polymer } \\
\text { infiltrated ceramic } \\
\text { network) }\end{array}$ & 2M2 & 41960 & $\begin{array}{l}\text { Ceramic part: } 86 \text { wt } \% / 75 \text { vol\%): } \mathrm{SiO}_{2}(58-63 \%), \mathrm{Al}_{2} \mathrm{O}_{3}(20-23 \%), \mathrm{NaO}_{2} \\
(9-11 \%), \mathrm{K}_{2} \mathrm{O}(4-6 \%), \mathrm{B}_{2} \mathrm{O}_{3}(0,5-2 \%), \mathrm{ZnO}_{2} \text { and } \mathrm{CaO}(<1 \%) \\
\text { Polymer part: } 14 \mathrm{wt} \% / 25 \text { vol\%, UDMA and TEGDMA. }\end{array}$ \\
\hline
\end{tabular}




\subsection{Characterization techniques}

\subsubsection{Profilometry}

Surface roughness (Ra) and film thickness were determined by stylus profilometry (Veeco, Dektak 150, New York, USA). The profilometer was set with a tip radius of $12.5 \mu \mathrm{m}$, in scans with $2000 \mu \mathrm{m}$ of extension during a time of $15 \mathrm{~s}$ and under a load of $3.0 \mathrm{mg}$. Five scans were completed on each specimen prior and immediately after film deposition $(\mathrm{n}=10)$.

Film thickness was measured from a step made onto a glass slide during the deposition, using Kapton adhesive tape as a mask. Five scans were accomplished on each glass slide immediately after film deposition $(n=4)$.

\subsubsection{Contact angle}

Water wettability was determined by contact angle goniometry (Rame-Hart 100-00, Rame-Hart Instruments, NJ, USA). Two droplets of deionized water $(0.2 \mu \mathrm{l}$ ea.) were deposited on different positions of the specimens. Contact angle was measured 10 times at each side of the droplets generating 10 mean values per sample. All measurements were taken prior and immediately after film deposition $(n=10)$.

\subsubsection{Scanning electron microscopy (SEM)}

Morphological analysis was assessed using SEM (JSM 610LA, JEOL; Tokyo, Japan). One disc from each group was examined $(n=1)$. Discs were metallized with a thin layer prepared by sputtering of an Au-Pd alloy before the reading and secondary electrons micrographs were captured using beam energies of 3 and $10 \mathrm{keV}$ at a $\times 10,000$ magnification.

\subsubsection{Fourier transform infrared spectroscopy (FTIR)}

The molecular structure of the films was inspected by Fourier transform infrared spectroscopy (Jasco FTIR 410 spectrometer, Tokyo, Japan). The spectra were the average of 128 scans acquired with $4 \mathrm{~cm}^{-1}$ of resolution.

Polished stainless steel plates, $15 \mathrm{~mm} \times 15 \mathrm{~mm} \times 0.5 \mathrm{~mm}$ (length $\times$ width $\times$ thickness) were used as reflective substrates to measure the intensity and wave number of the infrared radiation reflected while crossing the film and coming across the reflector's substrate $(n=3)$.

Infrared Reflectance Absorbance Spectroscopy (IRRAS) methodology was used to prevent the infrared radiation beam from interacting with the groups present on the substrate by using a reflective material, polished stainless steel, in this case. The radiation beam goes through the thin film and, upon reaching the substrate, it is reflected back again through the length of the thin film.

In addition, to avoid the appearance of peaks due to the substrate's groups in the spectrum, this methodology increases the intensity of the absorption bands because the beam passes twice throughout the film structure, improving the signal-to-noise ratio. Thus, the infrared spectra presented later on were collected from films deposited on polished stainless steel because the porcelain substrate does not reflect considerably infrared radiation. The compositional and structural analysis of the ceramic (porcelain) was performed by the XPS methodology.

\subsubsection{X-ray photoelectron spectroscopy}

To analyze elemental chemical composition, one specimen from each group was analyzed by X-ray photoelectron spectroscopy (XPS) (K$\mathrm{Alpha}^{\mathrm{TM}}+\mathrm{X}$-ray, Thermo Scientific) $(\mathrm{n}=1)$. The excitation X-ray source for the XPS used was AlKa at an energy level of $1361 \mathrm{eV}$, with a penetration depth of $<10 \mathrm{~nm}$.

\subsubsection{Color properties}

Color differences $(\Delta \mathrm{E})$ were studied using a visible spectrophotometer (CM-3770d, Konica Minolta, Japan). All specimens were analyzed before and after film deposition $(n=10)$. Color differences were determined by the following equation on standardize white backgrounds:

$\Delta \mathrm{E}=\left[\left(\mathrm{L}-\mathrm{L}_{0}\right)^{2}+\left(\mathrm{a}-\mathrm{a}_{0}\right)^{2}+\left(\mathrm{b}-\mathrm{b}_{0}\right)^{2}\right]^{1 / 2}$,

where the values for $\mathrm{L}$, $\mathrm{a}$, and $\mathrm{b}$ parameters were obtained from the coated specimens and on the same parameters obtained from the control groups $\left(\mathrm{L}_{0}, \mathrm{a}_{0}, \mathrm{~b}_{0}\right)$.

\subsubsection{Statistical analyzes}

Statistical analysis was performed using one-way ANOVA with repeated measures and post hoc multiple comparisons were made between groups by Tukey's post hoc test at a global significance level of $5 \%(\alpha=0.05)$. Data for $\Delta \mathrm{E}$ were analyzed using Kruskal-Wallis oneway analysis of variance on ranks and Dunn's test for multiple comparisons $(\alpha=0.05)$

\section{Results}

\subsection{Surface roughness and film thickness}

Surface average roughness (Ra) for all coated groups was maintained beneath $0.2 \mu \mathrm{m}$ threshold. There were no statistically significant differences in mean Ra values for all coated groups, when compared to their control groups, excluding PC-PAr and EN-PII groups, which showed a decrease $(p=0.023)$ and an increase $(p=0.001)$, respectively, compared to their control (Fig. 1).

Thin films presented statistically significant differences in mean thickness values among each other $(p<0.001)$. PAr coating showed statistically higher mean thickness, followed by $\mathrm{PO}_{2}$ and PII films (640 nm, $520 \mathrm{~nm}, 70 \mathrm{~nm}$, respectively).

\subsection{Wettability}

All thin film groups showed statistically significant higher mean contact angle values than their respective control groups ( $\mathrm{p}<0.001)$, with the exception of LU-PII group, which was statistically similar to LU-CTL, as shown in Fig. 2. PAr coatings presented the highest mean contact angle values $\left(\sim 90^{\circ}\right)$ while the lowest values were obtained for the PII group $\left(\sim 60^{\circ}\right)$. Samples exposed to $\mathrm{PO}_{2}$ presented intermediate values $\left(\sim 80^{\circ}\right)$ among those obtained in the first two groups.

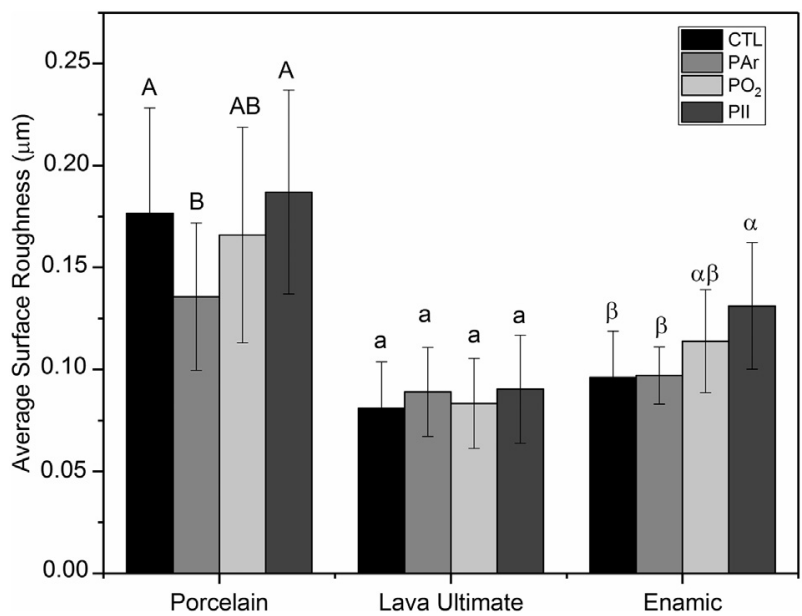

Fig. 1. Average surface roughness mean values and standard deviation of all studied groups divided by materials and experimental groups. For each material a specific statistical analyses was concluded. Different letters indicate mean values that are statistically different $(\mathrm{p}<0.05)$. 


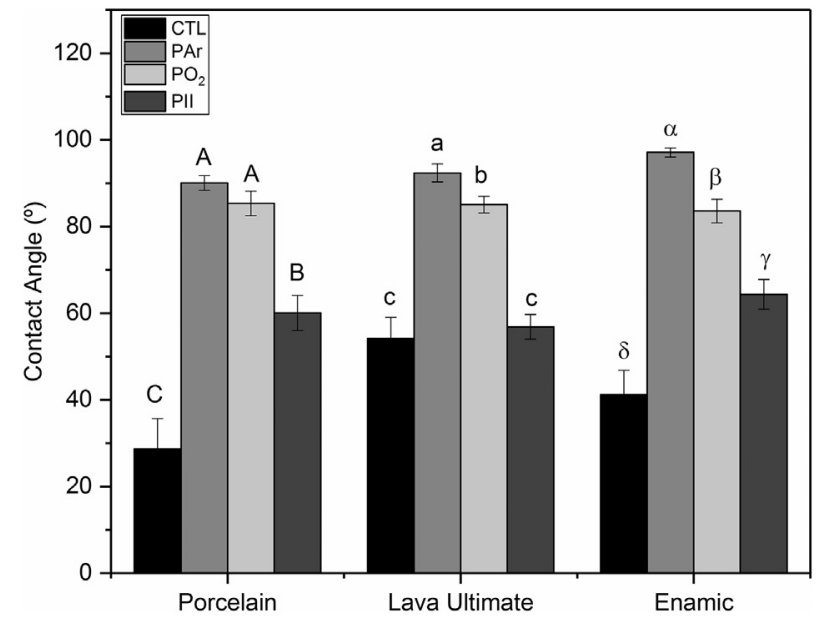

Fig. 2. Contact angle $\left({ }^{\circ}\right)$ mean values and standard deviation of all studied groups divided by materials and experimental groups. For each material a specific statistical analyses was accomplished. Different letters indicate mean values that are statistically different $(\mathrm{p}<0.05)$.

\subsection{Surface morphology}

In Fig. 3, SEM images demonstrated that the films uniformly coated the substrates without evidence of discontinuities. The presence of PAr and $\mathrm{PO}_{2}$ coatings on $\mathrm{LU}$ and EN produced the disappearance of scratches, probably due to mechanical polishing prior to film deposition, which are shown in the control groups, Fig. 3(E) and (I). Ball-like (rounded granular) structures were observed in both groups throughout the entire surface, appearing in a higher concentration and dimension for $\mathrm{PO}_{2}$ films, Fig. 3(C); (G) and (K). PC-PAr group showed smaller and fewer granular structures Fig. 3(B). The granular structures seemed to disappear or were shown in only specific areas of PII films, as shown in

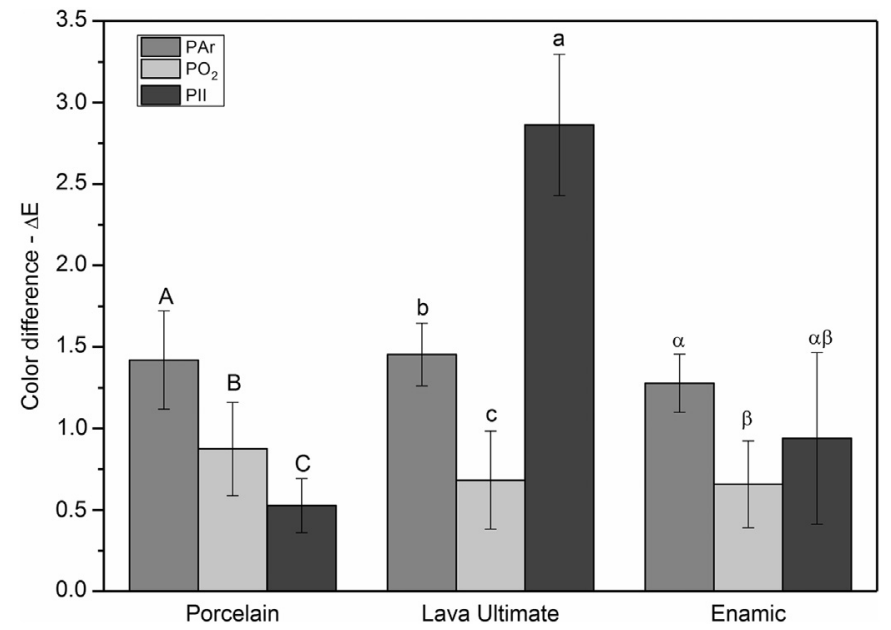

Fig. 4. Color difference values and standard deviation of all studied groups divided by materials and coatings. For each material, a specific statistical analysis was completed. Different letters indicate mean values that are statistically different $(\mathrm{p}<0.05)$.

Fig. 3(D); (H) and (L). Concerning morphological aspects of PII films, a surface with fewer imperfections was noted for all materials, indicating a smoother appearance, when compared to their control group, suggesting the presence of a thinner film. Thus, modifications produced by surface morphology were not only dependent on the type of coating but also on the substrate that was employed.

\subsection{Color difference $(\Delta E)$}

For all groups, color differences $(\Delta \mathrm{E})$ were lower than 3.0 as shown in Fig. 4. There were statistically significant differences among $\Delta \mathrm{E}$ values, for all coatings deposited on PC and LU, compared to their control
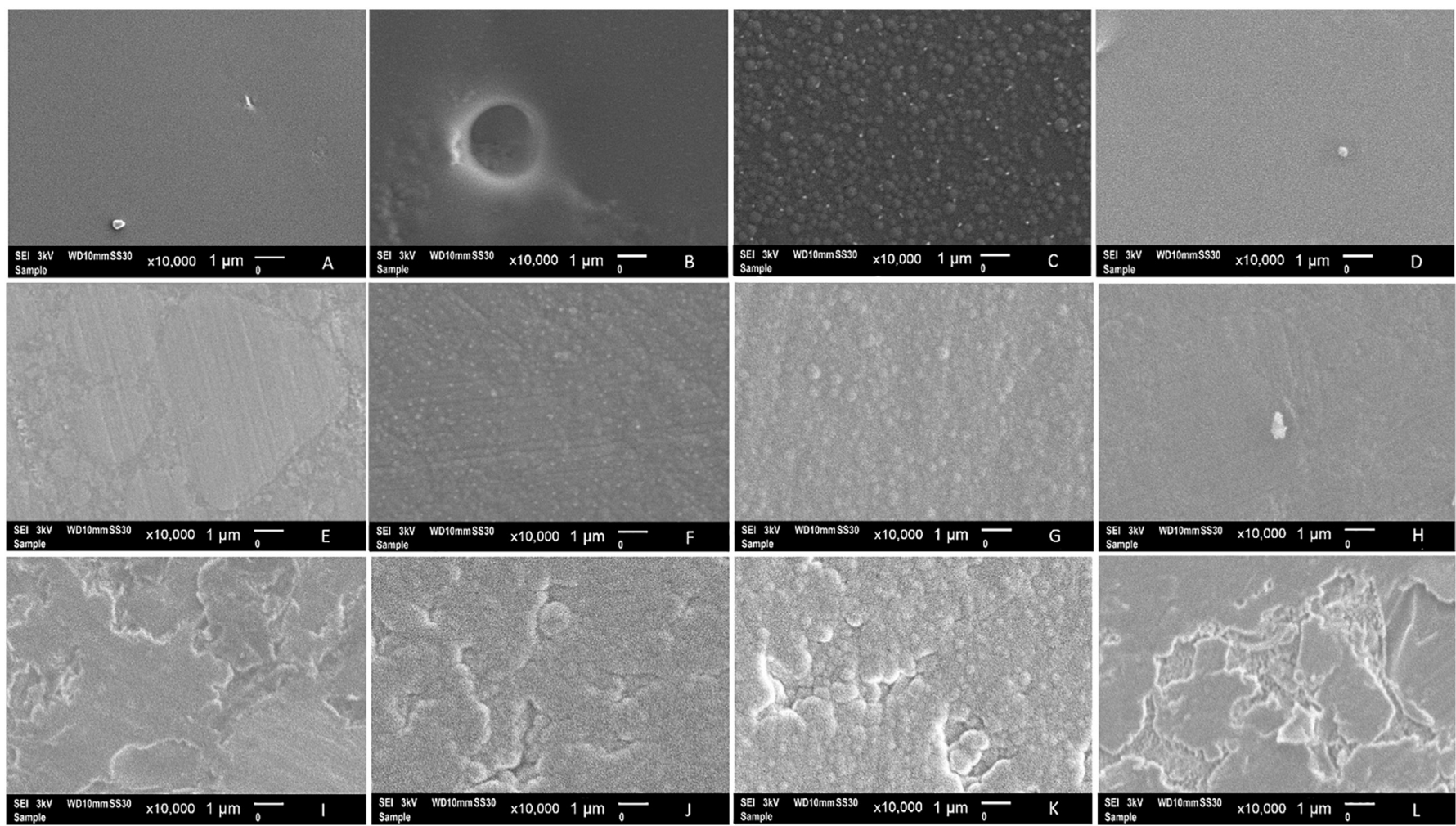

Fig. 3. Secondary electrons scanning electron micrographs of the surfaces divided by material and experimental groups at an $\times 10,000$ magnification. A) PC-CTL; B) PC-PAr; C) PC-PO ${ }_{2}$; D) PC-PII; E) LU-CTL; F) LU-PAr; G) LU-PO 2 ; H) LU-PII; I) EN-CTL; J) EN-Ar; K) EN-PO ${ }_{2}$; L) EN-PII. 


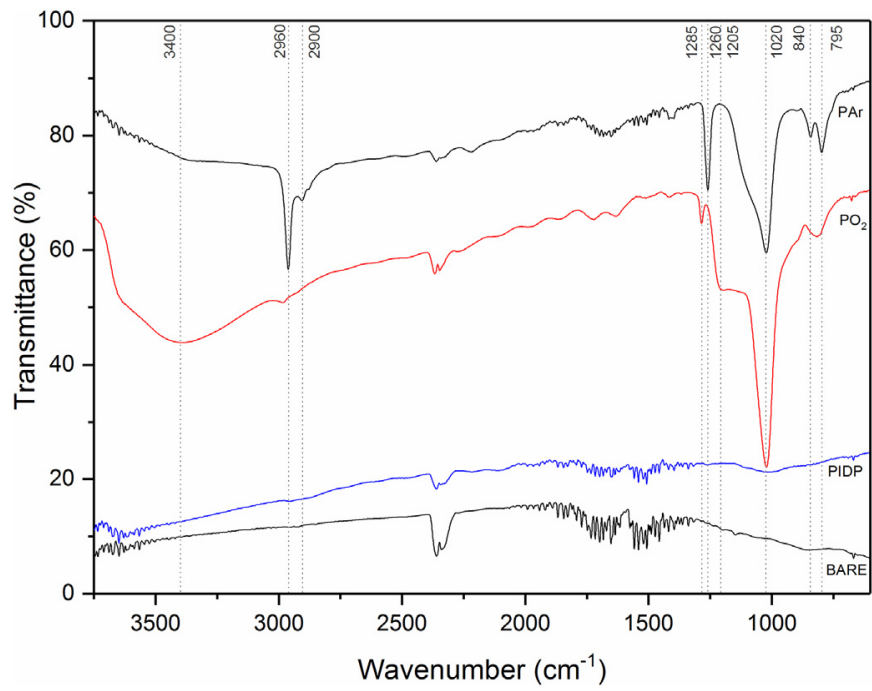

Fig. 5. FTIR spectra of the bare and coated samples produced from plasmas with argon (PAr), oxygen $\left(\mathrm{PO}_{2}\right)$ and argon (PII).

groups ( $\mathrm{p}<0.001)$. PC-PAr $(\Delta \mathrm{E}=1.42)$ and LU-PII $(\Delta \mathrm{E}=2.86)$ groups presented statistically higher mean color differences values compared to other coatings.

\subsection{Chemical structure and composition}

Fig. 5 shows FTIR spectra of the bare and coated stainless steel samples deposited with argon and oxygen dilutions. The samples from $\mathrm{PAr}$ and $\mathrm{PO}_{2}$ groups present roughly, the same absorption bands indicating the presence of $\mathrm{C}-\mathrm{H}\left(2960,2900 \mathrm{~cm}^{-1}\right), \mathrm{Si}-\mathrm{O}(1020$ a $\left.1205 \mathrm{~cm}^{-1}\right)$ and methylsilil Si[CH3 $]_{\mathrm{x}}\left(1260,840\right.$ e $\left.795 \mathrm{~cm}^{-1}\right)$ groups [31-33]. The band between 1020 and $1205 \mathrm{~cm}^{-1}$ can be decomposed into two overlapping bands (1080 and $\left.1030 \mathrm{~cm}^{-1}\right)$ which are generated by the vibration of $\mathrm{Si}-\mathrm{O}$ groups in $\mathrm{Si}-\mathrm{O}-\mathrm{C}$ and in $\mathrm{Si}-\mathrm{O}-\mathrm{Si}$, respectively [31,34].

Furthermore, the spectra of $\mathrm{PAr}$ and $\mathrm{PO}_{2}$ films presented the rise of bands around 840 and $795 \mathrm{~cm}^{-1}$, related to $\mathrm{Si}\left[\mathrm{CH}_{3}\right]_{\mathrm{x}}$ bending mode, revealing the preservation of HMDSO fragments in the film structure. The presence of methylsilyl groups, especially in the film prepared in the presence of $\mathrm{Ar}$ (PAr), allows classifying the structure as an organosilicon in which the main chain is composed of $\mathrm{Si}-\mathrm{O}-\mathrm{Si}$ groups. The methyl groups are connected to the $\mathrm{Si}$ atoms, producing, in average, two methyl groups connected to each $\mathrm{Si}$ atom, as in the conventional silicon (polydimethylsiloxane) $\left(\mathrm{SiO}_{2}\left(\mathrm{CH}_{3}\right)_{2}\right)$.

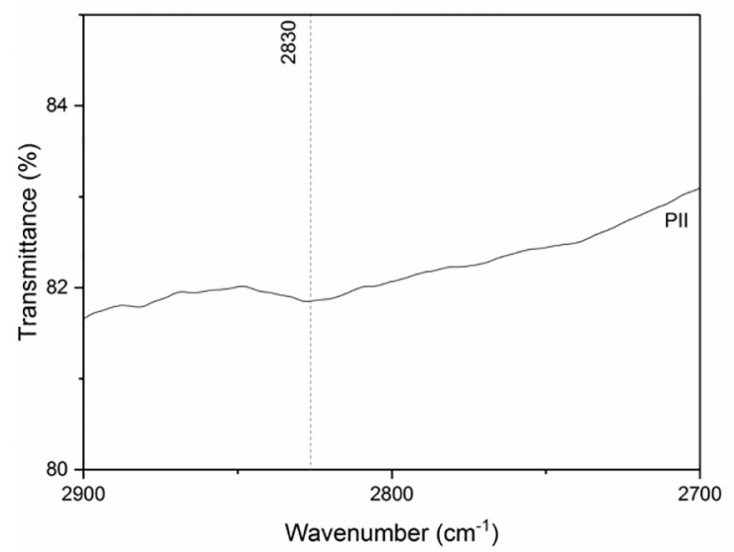

Despite the higher thickness of the film deposited under Ar dilution $(640 \mathrm{~nm})$ the overall higher intensity of the peaks in the spectrum of the film prepared under oxygen dilution $(520 \mathrm{~nm})$ is attributed to a higher density of the last coating. In addition, a decrease in the intensity of bands related to methyl groups $\left(2960,2900\right.$ and $1260 \mathrm{~cm}^{-1}$ ) is observed when oxygen is used in the dilution of HMDSO instead of Ar ( $\mathrm{PO}_{2}$ group). It is also noted an enlargement in the band around $\sim 1000 \mathrm{~cm}^{-1}$, indicating an increase in the proportion of $\mathrm{Si}-\mathrm{O}-\mathrm{C}$ groups, and the appearance of silanol groups $(\mathrm{Si}-\mathrm{OH})$, evidenced by the intense absorption $3305 \mathrm{~cm}^{-1}$ in the spectrum of the deposited film with the presence of oxygen $\left(\mathrm{PO}_{2}\right)$ [35]. This result points out to the removal of the following components $\mathrm{H}, \mathrm{CH}, \mathrm{CH}_{2}$ and $\mathrm{CH}_{3}$ from the structure when oxygen is present during the deposition process, promoting the transition from a typical organosilicon structure to another one with a lower proportion of methyl groups, but still containing C. The loss of $\mathrm{H}$ gives a rise to pendant bonds, which are saturated by chains crosslinking, turning the structure denser than conventional polydimethylsiloxane (PDMS).

On the other hand, films prepared under ion bombardment (PII group) resulted in a featureless spectrum. This result is owing to the low sensibility of this approach to structures with reduced thicknesses $(\sim 70 \mathrm{~nm})$. However, the amplification of this spectrum, shown in Fig. 6, allows the detection of $\mathrm{C}-\mathrm{H}\left(\sim 2900 \mathrm{~cm}^{-1}\right)$ and $\mathrm{Si}-\mathrm{O}-\mathrm{Si}$ $\left(\sim 1000 \mathrm{~cm}^{-1}\right)$ groups [36,37].

\subsection{X-ray photoelectron spectroscopy}

The atomic ratio of the chemical elements presented in XPS analysis is shown in Table 2. XPS analyses demonstrated that feldspathic VM9 porcelain is composed of about $62.0 \% \mathrm{O}, 23.5 \% \mathrm{Si}, 3.85 \% \mathrm{~K}, 6.82 \% \mathrm{Al}$, $1.43 \% \mathrm{Na}, 1.20 \% \mathrm{Ca}$ and $<1 \%$ of $\mathrm{Mg}$, $\mathrm{Zr}$ and $\mathrm{Ba}$. Lava Ultimate presented $43 \% \mathrm{O}, 13 \% \mathrm{Si}, 40 \% \mathrm{C}, 2 \% \mathrm{~N}$ and $2 \% \mathrm{Zr}$ and Enamic, $43 \% \mathrm{O}$, $13 \% \mathrm{Si}, 32 \% \mathrm{C}, 1 \% \mathrm{~K}, 5 \% \mathrm{Al}, 3 \% \mathrm{Na}, 2 \% \mathrm{~N}$, and $<1 \% \mathrm{Mg}$ and $\mathrm{Ca}$.

In general, when the films are deposited on the material's surface, the characteristic elements of the substrate $(\mathrm{K}, \mathrm{AL}, \mathrm{Na}, \mathrm{N}, \mathrm{Zr}, \mathrm{Mg}, \mathrm{Ca}$ and $\mathrm{Ba}$ ) are no longer present indicating that the detected elements represent the chemical composition of the film alone. Regardless of the substrate employed, within the experimental error (10 to 20\%), PAr coatings can be characterized as an organosilicon, as it has about $50 \% \mathrm{C}$ like the conventional silicone structure (50\% C $25 \% \mathrm{Si}$ and $25 \% \mathrm{O}$ ).

However, the film prepared using $\mathrm{O}_{2}$ dilution presented a substantially reduced concentration of C (4-25\%), consequently this structure cannot be characterized as an organosilicon but as a silica-like structure $(66 \% \mathrm{O}$ and $33 \% \mathrm{Si}$ ), illustrated in Fig. 7 with contents of C contamination dependent on the substrate type. The proportion of $\mathrm{C}$ in the resulting structure was also reduced (13-23\%) when ion bombardment was associated with the film deposition process (PII group)

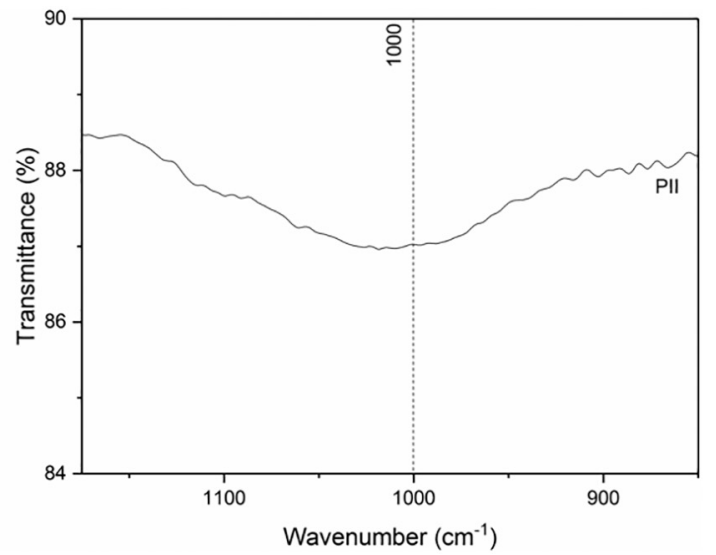

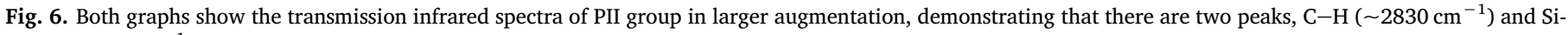
O-Si $\left(\sim 1000 \mathrm{~cm}^{-1}\right)$ groups. 
Table 2

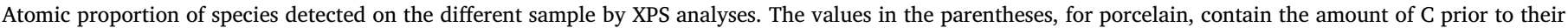
subtraction from the total amount.

\begin{tabular}{|c|c|c|c|c|c|c|c|c|c|c|c|c|c|}
\hline XPS (\%) & & & & & & & & & & & & & \\
\hline Material & Group & $\mathrm{O}$ & $\mathrm{Si}$ & $\mathrm{C}$ & $\mathrm{K}$ & $\mathrm{Al}$ & $\mathrm{Na}$ & $\mathrm{N}$ & $\mathrm{Zr}$ & $\mathrm{Fe}$ & $\mathrm{Ca}$ & $\mathrm{Mg}$ & $\mathrm{Ba}$ \\
\hline \multirow[t]{4}{*}{ Porcelain } & CTL & $\begin{array}{l}61.98 \\
(50.73)\end{array}$ & $\begin{array}{l}23.50 \\
(19.23)\end{array}$ & $\begin{array}{l}0 \\
(18.15)\end{array}$ & $\begin{array}{l}3.85 \\
(3.15)\end{array}$ & $\begin{array}{l}6.82 \\
(5.58)\end{array}$ & $\begin{array}{l}1.43 \\
(1.17)\end{array}$ & 0 & $\begin{array}{l}0.41 \\
(0.34)\end{array}$ & 0 & $\begin{array}{l}1.20 \\
(0.99)\end{array}$ & $\begin{array}{l}0.61 \\
(0.5)\end{array}$ & $\begin{array}{l}0.22 \\
(0.16)\end{array}$ \\
\hline & PAr & 25.88 & 26.51 & 47.61 & 0 & 0 & 0 & 0 & 0 & 0 & 0 & 0 & 0 \\
\hline & $\mathrm{PO}_{2}$ & 63.68 & 32.01 & 4.31 & 0 & 0 & 0 & 0 & 0 & 0 & 0 & 0 & 0 \\
\hline & PII & 57.66 & 26.93 & 13.07 & 0 & 0 & 0 & 0 & 0 & 0 & 0 & 0 & 0 \\
\hline \multirow[t]{4}{*}{ Lava Ultimate } & CTL & 42.67 & 13.32 & 39.69 & 0 & 0 & 0 & 2.09 & 2.23 & 0 & 0 & 0 & 0 \\
\hline & PAr & 32.75 & 26.66 & 39.82 & 0 & 0 & 0 & 0 & 0 & 0 & 0 & 0 & 0 \\
\hline & $\mathrm{PO}_{2}$ & 45.38 & 29.35 & 25.28 & 0 & 0 & 0 & 0 & 0 & 0 & 0 & 0 & 0 \\
\hline & PII & 54.18 & 23.53 & 18.09 & 0 & 0 & 1.36 & 0 & 0 & 2.02 & 0 & 0 & 0 \\
\hline \multirow[t]{4}{*}{ Enamic } & CTL & 42.94 & 12.73 & 32.37 & 0.92 & 5.18 & 2.55 & 2.19 & 0 & 0 & 0.75 & 0.37 & 0 \\
\hline & $\mathrm{PAr}$ & 25.26 & 26.89 & 47.38 & 0 & 0 & 0 & 0 & 0 & 0 & 0 & 0 & 0 \\
\hline & $\mathrm{PO}_{2}$ & 56.55 & 31.11 & 12.34 & 0 & 0 & 0 & 0 & 0 & 0 & 0 & 0 & 0 \\
\hline & PII & 49.51 & 18.55 & 23.58 & 0 & 0 & 0 & 1.59 & 0 & 4.25 & 0 & 0 & 0 \\
\hline
\end{tabular}

generating another distinct silicon based structure which can no longer be identified as organosilicon or silica but as a silicon oxycarbide-like structure $\left(\mathrm{SiC}_{\mathrm{x}} \mathrm{O}_{\mathrm{y}}\right)$, illustrated in Fig. 7.

\section{Discussion}

The first hypothesis was partially accepted due to variations in mean delta $\mathrm{E}$ and Ra values that occurred in specific groups. According to previous studies [38,39], a smooth restorative surface must be under the threshold roughness of $0.2 \mu \mathrm{m}$, avoiding issues such as excessive bacterial adhesion and wear of the restorative material or opposing tooth.

The presence of PAr thin film could have decreased the porcelain's Ra due to the filling of the pores and irregularities of the as-received substrate surface by the coating [20]. For EN-PII, the association of ion bombardment to the deposition process possibly caused an augmentation of defects present on the surface of the specimens due to the higher energy provided to the growing surface by ion bombardment. There is a limitation regarding the polished surfaces in this study compared to the reality seen in dental practice, because of a more smoothen and controlled surface, when accomplished in the laboratory. Therefore, surface roughness results may differ when the polishing process is altered.
Alterations in wettability, roughness and morphology are clinically interesting, as seen in previous studies that show how these properties could have direct influence on bacterial adhesion, biofilm formation, and the survival of the restoration [39-41]. Nonetheless, in order to modify the material's surface and properties, a particular characteristic must be maintained, that is the color of the aesthetic restorative material. Color match and stability throughout the functional period of the restoration is as important as the mechanical and superficial properties of the material $[42,43]$.

Polymeric thin films derived from HMDSO are considered transparent in the visible spectra [44]. There are divergences in the literature regarding the threshold for an acceptable $\Delta \mathrm{E}$ value for aesthetic restorative dental material. Some reports established a $\Delta \mathrm{E}$ of 3.7 as acceptable [45], others described an acceptable threshold of 2.72 [46], 3.3 [47] and 4.2 [48]. All films in the present study maintained $\Delta \mathrm{E}$ values under the clinically acceptable value for major studies $(\Delta \mathrm{E}<3)$ demonstrating a satisfactory color difference.

In regards to the second hypothesis, concerning that the wettability, surface morphology and chemical composition of the surfaces would be altered by the presence of the thin films, it was accepted. All materials studied presented a hydrophilic surface, with contact angles ranging from 29 to $66^{\circ}$. With the presence of the thin films deposited by plasma-

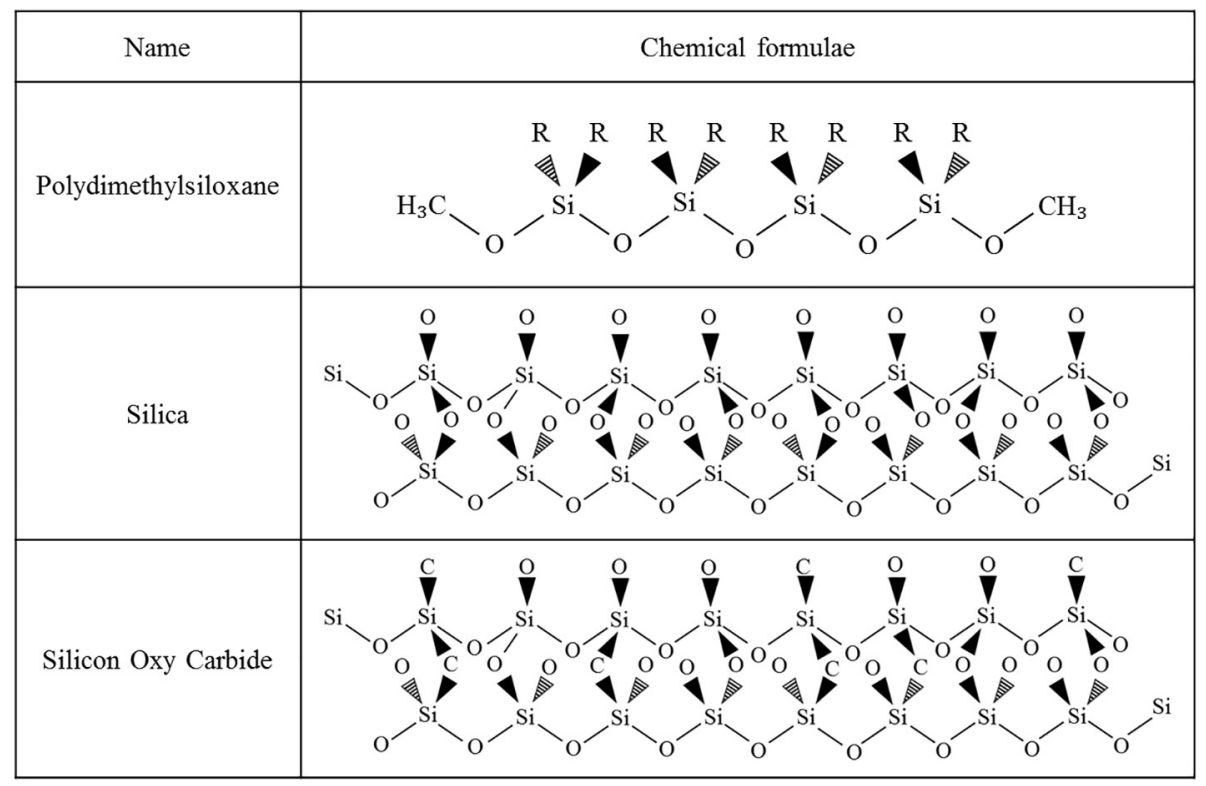

Fig. 7. Chemical formulae of the different components found in the three films developed. 
enhanced chemical vapor deposition ( $\mathrm{PAr}$ and $\left.\mathrm{PO}_{2}\right)$, the contact angle increased (to 90 and $80^{\circ}$, respectively). The hydrophobic nature of the surfaces treated using Ar dilution is consistent with the organosilicon nature of the films [20]. Since silica-like films were identified on the surfaces exposed to deposition using $\mathrm{O}_{2}$ dilution $\left(\mathrm{PO}_{2}\right)$, it was expected a more hydrophilic surface than the organosilicon-containing ones. The materials, which received the PII coatings, on the other hand, demonstrated only a slight increase in the value of the contact angles $\left(\sim 60^{\circ}\right)$ consistently with the presence of a hydrophilic silicon-oxy carbide thin film, as reported in a study of Wan et al. [49], which characterized SiDLC films produced by plasma immersion ion implantation and deposition hybrid technique. Therefore, it was demonstrated that different methodologies result in surfaces with different thermodynamic natures.

Plasma-deposited thin films can be tailored according to specific needs, altering deposition techniques, gas/vapor proportions, power supply and deposition time [21,23]. The different techniques influenced the coatings wettability, in distinct manners. As seen in previous studies, organosilicon plasma-enhanced chemical vapor deposition-deposited thin films in HMDSO, $\mathrm{O}_{2}$ and/or Ar atmospheres, are characteristically hydrophobic [20,50,51]. On the other hand, studies demonstrated hydrophilic surfaces when the hybrid implantation and deposition technique (PII group) was used to deposit the film associated with a post-deposition argon plasma treatment, as conducted here [52-54]. The present study did not provide correlations between roughness and wettability trends. Differences in chemical composition of the films seem to be the main responsible for the wettability alterations of the different surfaces studied.

Film thickness also varied according to the plasma deposition technique, in which plasma-enhanced chemical vapor deposition coatings showed mean thickness values of almost 10 times higher than for plasma immersion ion implantation and deposition coating. The present results indicate that a compaction occurs during the hybrid plasma process which was followed by post deposition-argon treatment (PII) that also contributes to reducing film's thickness due to ion ablation phenomenon [25]. An advantageous feature of these coatings are their very thin thicknesses obtained by these plasma techniques, which possibly do not interfere with restoration adaptation and color, as evidenced in the results of this present study and decreases the risk of a cohesive rupture of the film.

Scanning electron micrographs presented pores and irregularities, probably from substrate finishing prior to film deposition, were detected on the uncoated porcelain and the indirect resin composites, respectively. After the film depositions, such defects and even pores were covered or smoothened, altering the morphological characteristics of the different substrates. The micrographs show that the thin films covered the entire surfaces of the porcelain and indirect resin composites.

Ball-like structures, formed by the oligomerization of HMDSO fragments originated in the plasma phase $[30,37]$, with larger dimensions and clusters were also evidenced on $\mathrm{PO}_{2}$ coatings probably due to the effect of oxygen on the chemical activation of the precursor molecule when compared to PAr films [20]. SEM images from PII group displayed different morphological changes probably as a result of the difference in film deposition kinetics.

For $\mathrm{PO}_{2}$ films, the presence of oxygen in the plasma increases the fragmentation of the HMDSO compound, augmenting the plasma phase reaction. The recombination rate of the species in the plasma phase grows generating clusters of organosilicon material that settles on the surface and connects to those previously deposited. This explains the higher concentration of the ball-like structures on the surface of films deposited in the presence of oxygen. When argon is used (PAr), the polymerization reaction in the plasma phase is reduced, as well as the concentration and diameter of the agglomerates. Ionic bombardment during the deposition process, however, provides sufficient energy to fragment bonds in the growing solid and to fuse the possible granular structures present. The recoil of film species to the substrate induced by the bombardment also explains the lower deposition rates obtained in this methodology.

FTIR results for PAr presented the main vibrational modes of the monomer molecule (HMDSO), demonstrating preservation of organosilicon fragments in the film structure [21]. The retention of silicon in the coatings is evidenced by absorptions around 1020 (v Si-O) [31,34] and in the low wavenumber region (v 700-850) as previously reported $[20,55]$. Higher vibrational peaks present in PAr, at $2960 \mathrm{~cm}^{-1}$, $1260 \mathrm{~cm}^{-1}, 800-795 \mathrm{~cm}^{-1}$, than in $\mathrm{PO}_{2}$ group confirm a more organic character of the first film. With the presence of oxygen in the mixture, a decrease in the vibrations in the $\mathrm{CH}_{3}$ bands is observed along with the presence of a new broad absorption band at $3100-3500 \mathrm{~cm}^{-1}$, suggesting the presence of $\mathrm{Si}-\mathrm{OH}$ bonds, since this peak is attributed to $\mathrm{OH}$ stretching [56,57]. PII group showed fewer bands mainly caused by thinner thickness $(70 \mathrm{~nm})$ of the film, in comparison to the other coatings. However, there were two peaks that were able to be observed when amplified, with the detection of Si-O-Si $\left(\sim 1000 \mathrm{~cm}^{-1}\right)$ and $\mathrm{v} \mathrm{C}-\mathrm{H}$ groups $\left(\sim 2900 \mathrm{~cm}^{-1}\right)$ [36,37].

The presence of $\mathrm{CH}_{3}$ non-polar groups on the surface of the PAr prepared samples (Fig. 5) explains the low receptivity to water. The methyl groups shields the polar Si-O-Si groups vanishing their electrostatic effect on the polar water molecules. Differently occur for the $\mathrm{PO}_{2}$ (silica-like) and PII (silicon oxy carbide-like) prepared samples, since higher proportions of methyl groups are abstracted during the deposition, thus explaining the higher affinity of these two samples towards water $[49,58]$.

Finally, the subtraction of the elements from the structure leads to the creation of free radicals that can absorb $\mathrm{OH}$ groups generated during the deposition process or when the sample is withdrawn from the vacuum chamber and exposed to air. This phenomenon explains the appearance of silanol groups $(\mathrm{Si}-\mathrm{OH})$, evidenced by the intense absorption $3305 \mathrm{~cm}^{-1}$ in the spectrum shown in $\mathrm{PO}_{2}$ group [35].

Comparisons between the coated and uncoated specimens showed the disappearance of core elements of each material, which demonstrate that the surfaces' were completely covered by the thin films (Table 2). Along with FTIR results, XPS analyses were able to confirm evidences of the formation of three different films, as described in this study.

Chemical analysis revealed the abnormal presence of carbon (C) on the uncoated porcelain substrates (PC-CTL), varying their atomic proportions $\sim 18 \%$. There is no conclusive response on the reason why this component was found, but there are studies, which hypothesize that the presence of $\mathrm{C}$ could be a contamination from the sintering process, polishing techniques prior to the analysis [59], or organic additives present in the ceramic $[60,61]$. There are other studies that bring the chemical proportions of the porcelain with and without the presence of $\mathrm{C}$, [62] as done in this study, or even report the obtained values and do not go in further details on the presence of this element [63]. Feldspathic VM9 porcelain, Enamic and Lava Ultimate chemical composition, obtained from XPS analyses, were consistent to previous studies $[59,62,64,65]$ and showed agreement with the atomic proportions obtained in previous works [66-69].

For the coated groups, XPS analyses showed chemical differences between both plasma-enhanced chemical vapor deposition-deposited coatings, in which PAr results displayed a high carbon (C) content (approaching 50\%), followed by silicon ( $\mathrm{Si})(\sim 30 \%)$ and $(\sim 25 \%)$ of oxygen (O). This finding is also in accordance with other reports, which present similar XPS results of HMDSO/Ar [70] and $\mathrm{HMDS} / \mathrm{O}_{2} / \mathrm{Ar}$ dilutions [71] and match the composition of conventional polydimethylsiloxane [72,73].

However, the $\mathrm{PO}_{2}$ film demonstrated an inversion in the $\mathrm{C}$ and $\mathrm{O}$ content, with an overall reduction in C content, $\sim 15$ and $\sim 50 \%$, respectively, along with a maintained value of $\mathrm{Si}, \sim 30$. Interestingly, the chemical composition results complement very well those obtained by infrared spectroscopy for $\mathrm{PAr}$ and $\mathrm{PO}_{2}$ groups. PII group results showed a similar behavior, in which there was a decrease in $\mathrm{C}$ content and 
increase in $\mathrm{O}$.

When these findings are combined to FTIR, wettability and SEM results, it can be inferred that $\mathrm{PO}_{2}$ and PII groups have structural differences, even though both have a silicon-based structure, with a reduced content of C. A silica-like [50] and silicon oxycarbide-like [58] structure, respectively, are seen for these groups, while PAr coating presented a typical organosilicon structure.

Very few studies with economic feasibility of the low pressure plasma methodology were performed up to now. However, in a previous study, the economic viability of low pressure plasma methodology for the treatment of devices used in the automobile industry was evaluated [74-76]. In these studies, a steel forming tool was subjected to PIIID procedure in acetylene $\left(\mathrm{C}_{2} \mathrm{H}_{2}\right)$ diluted in argon atmosphere, aiming to deposit protective coating, which would increase the device lifetime. The hypothesis that the coated materials would show a lower friction coefficient preventing the metallic surface wear, and consequently, increasing durability was validated by morphological, topographical and tribological analysis. In the mentioned researches, the necessary costs for the treatment of flat pieces were estimated to be less than $\$ 1$. That is, even if it involves sophisticated concepts, a lowpressure plasma methodology is financially feasible while low-value added applications are considered.

Furthermore, plasma reactors are already available in the market for treatments of small parts or quantities (prototypes for offices, for example), as well as for large-scale productions. Low-pressure plasmas are excited at low pressures $\left(10^{-2}\right.$ Torr) and the power, (power necessary is equivalent to that of a residential lamp, $<200 \mathrm{~W}$ ). For the same reason, the expense with the chemical compounds involved is very little, as is the volume of waste generated in the process. Such residues are fragments of the starting compounds that are not harmful to the operator and the environment, reason why they do not require treatments before being emitted.

The association of these factors confirms that the methodology used in this present research is simple to be carried out, economically feasible and ecologically correct, reason why it has been extensively investigated for applications in different productive sectors as well as in dentistry and medicine. In this matter, treatments with low-pressure plasmas represent an innovative methodology which is financially more viable than others traditionally employed (humid and thermal methods) for the treatments in question.

\section{Conclusions}

Plasma-deposited thin films modified specific surface properties of three different indirect restorative materials maintaining their color and low surface roughness. Considering the same organometallic starting compound, HMDSO, different plasma deposition methodologies allowed the creation of structures with different chemical compositions, densities and wettability. The parameters used in this study such as gas components, pressure, time, power and plasma deposition technique all influenced the changes and were capable of developing unique coatings that have promising protective barrier results and should be further studied to identify mechanical and/or biological modifications on dental materials. The present study reveals a recognizable potential of application in the area of Biomaterials, since the coating of restorative materials with thin films deposited by plasma could influence its surface characteristics, as well as be modified according to specific conditions.

\section{Acknowledgements}

The authors acknowledge the assistance of Brazilian Nanotechnology National Laboratory for the XPS analyses, Jamille Altheman from the Technological Plasmas Laboratory for the SEM images and 3M ESPE for the Lava Ultimate CAD/CAM blocks.

\section{Funding}

This work was partially supported by the grant agency $\mathrm{CNPq}$ (Conselho Nacional de Desenvolvimento Científico e Tecnológico), Brazil, [process number: 140063/2014-5].

\section{Conflict of interest}

The authors declare that they have no conflict of interest.

\section{References}

[1] J.R. Kelly, Ceramics in restorative and prosthetic dentistry, Annu. Rev. Mater. Sci. 27 (1997) 443-468.

[2] C.A.D. Costa, H.M. Teixeira, A.B.L. do Nascimento, J. Hebling, Biocompatibility of resin-based dental materials applied as liners in deep cavities prepared in human teeth, J. Biomed. Mater. Res. B Appl. Biomater. 81B (2007) 175-184.

[3] M.S. Cho, Y.K. Lee, B.S. Lim, Y.J. Lim, Changes in optical properties of enamel porcelain after repeated external staining, J. Prosthet. Dent. 95 (2006) 437-443.

[4] G. Sinmazisik, M.L. Ovecoglu, Physical properties and microstructural characterization of dental porcelains mixed with distilled water and modeling liquid, Dent. Mater. 22 (2006) 735-745.

[5] A. Harada, K. Nakamura, T. Kanno, R. Inagaki, U. Ortengren, Y. Niwano, et al., Fracture resistance of computer-aided design/computer-aided manufacturing-generated composite resin-based molar crowns, Eur. J. Oral Sci. 123 (2015) 122-129.

[6] C. Chen, F.Z. Trindade, N. de Jager, C.J. Kleverlaan, A.J. Feilzer, The fracture resistance of a CAD/CAM resin nano ceramic (RNC) and a CAD ceramic at different thicknesses, Dent. Mater. 30 (2014) 954-962.

[7] M. Bourbia, D. Ma, D.G. Cvitkovitch, J.P. Santerre, Y. Finer, Cariogenic bacteria degrade dental resin composites and adhesives, J. Dent. Res. 92 (2013) 989-994.

[8] Y. Finer, J.P. Santerre, Salivary esterase activity and its association with the biodegradation of dental composites, J. Dent. Res. 83 (2004) 22-26.

[9] M.V. Swain, Impact of oral fluids on dental ceramics: what is the clinical relevance? Dent. Mater. 30 (2014) 33-42.

[10] R. Morena, G.M. Beaudreau, P.E. Lockwood, A.L. Evans, C.W. Fairhurst, Fatigue of dental ceramics in a simulated oral environment, J. Dent. Res. 65 (7) (1986) 993.

[11] B.P. Ornaghi, M.M. Meier, V. Rosa, P.F. Cesar, U. Lohbauer, R.R. Braga, Subcritical crack growth and in vitro lifetime prediction of resin composites with different filler distributions, Dent. Mater. 28 (2012) 985-995.

[12] G.M. Loughran, A. Versluis, W.H. Douglas, Evaluation of sub-critical fatigue crack propagation in a restorative composite, Dent. Mater. 21 (2005) 252-261.

[13] E.D. Rekow, N.R.F.A. Silva, P.G. Coelho, Y. Zhang, P. Guess, V.P. Thompson, Performance of dental ceramics: challenges for improvements, J. Dent. Res. 90 (2011) 937-952.

[14] J.L. Drummond, Degradation, fatigue, and failure of resin dental composite materials, J. Dent. Res. 87 (2008) 710-719.

[15] V. Rosa, H.N. Yoshimura, M.M. Pinto, C. Fredericci, P.F. Cesar, Effect of ion exchange on strength and slow crack growth of a dental porcelain, Dent. Mater. 25 (2009) 736-743.

[16] S.F. Rosenstiel, I.L. Denry, W. Zhu, P.K. Gupta, R.A. Vandersluys, Fluoroalkylethyl silane coating as a moisture barrier for dental ceramics, J. Biomed. Mater. Res. 27 (1993) 415-417.

[17] S. Yodmongkol, R. Chantarachindawong, S. Thaweboon, B. Thaweboon, T. Amomsakchai, T. Srikhirin, The effects of silane- $\mathrm{SiO}_{2}$ nanocomposite films on Candida albicans adhesion and the surface and physical properties of acrylic resin denture base material, J. Prosthet. Dent. 112 (2014) 1530-1538.

[18] W.W. Zuo, D. Feng, A.Y. Song, H.H. Gong, S. Zhu, Effects of organic-inorganic hybrid coating on the color stability of denture base resins, J. Prosthet. Dent. 115 (2016) 103-108.

[19] D. Feng, H.H. Gong, J.H. Zhang, X.W. Guo, M. Yan, S. Zhu, Effects of antibacterial coating on monomer exudation and the mechanical properties of denture base resins, J. Prosthet. Dent. 117 (2017) 171-177.

[20] C. Vendemiatti, R.S. Hosokawa, R.C.C. Rangel, J.R.R. Bortoleto, N.C. Cruz, E.C. Rangel, Wettability and surface microstructure of polyamide 6 coated with SiOXCYHZ films, Surf. Coat. Technol. 275 (2015) 32-40.

[21] R. Rangel, T.C. Pompeu, J.L.S. Barros Jr., C.A. Antonio, A.M. Santos, B.O. Pelici, C.M.A. Freire, N.C. Cruz, E.C. Rangel, Improvement of the corrosion resistance of carbon steel by plasma deposited thin films, in: R.S. Razavi (Ed.), Resistance of Carbon Steel by Plasma Deposited Thin Films, Intech, 2012, p. 152.

[22] M. Sandhyarani, N. Rameshbabu, K. Venkateswarlu, L.R. Krishna, Fabrication, characterization and in-vitro evaluation of nanostructured zirconia/hydroxyapatite composite film on zirconium, Surf. Coat. Technol. 238 (2014) 58-67.

[23] H. Yasuda, Plasma Polymerization, Academic Press, INC, Orlando, Florida, 1985.

[24] F.L. Freire, M.E.H.M. da Costa, L.G. Jacobsohn, D.F. Franceschini, Film growth and relationship between microstructure and mechanical properties of a-C: H: F films deposited by PECVD, Diam. Relat. Mater. 10 (2001) 125-131.

[25] R.M. Santos, R. Turri, E.C. Rangel, N.C. da Cruz, W. Schreiner, C.U. Davanzo, et al., Diverse amorphous carbonaceous thin films obtained by plasma enhanced chemical vapor deposition and plasma immersion ion implantation and deposition, Phys. Procedia 32 (2012) 48-57.

[26] T. Hayakawa, M. Yoshinari, K. Nemoto, Characterization and protein-adsorption behavior of deposited organic thin film onto titanium by plasma polymerization 
with hexamethyldisiloxane, Biomaterials 25 (2004) 119-127.

[27] A.J. Vechiato-Filho, I. da Silva Vieira Marques, D.M. dos Santos, A.O. Matos, E.C. Rangel, N.C. da Cruz, et al., Effect of nonthermal plasma treatment on surface chemistry of commercially-pure titanium and shear bond strength to autopolymerizing acrylic resin, Mater. Sci. Eng. C 60 (2016) 37-44.

[28] D.M. dos Santos, A.J. Vechiato-Filho, E.V.F. da Silva, M. Coelho Goiato, P. Francisco Cesar, E. Cipriano Rangel, et al., Aging effect of atmospheric air on zirconia surfaces treated by nonthermal plasma, J. Adhes. Dent. 17 (2015) 413-419.

[29] S. Zanini, C. Riccardi, M. Orlandi, E. Grimoldi, Characterisation of SiOxCyHz thin films deposited by low-temperature PECVD, Vacuum 82 (2007) 290-293.

[30] B. Lopes, R.C.C. Rangel, C.A. Antonio, S.F. Durrant, N.C. Cruz, E.C. Rangel, Mechanical and tribological properties of plasma deposited a-C:H:Si:O films, in: J. Nemecek (Ed.), Nanoindentation in Materials Science, InTech, 2012, p. 308.

[31] T.R. Gengenbach, H.J. Griesser, Post-deposition ageing reactions differ markedly between plasma polymers deposited from siloxane and silazane monomers, Polymer 40 (1999) 5079-5094.

[32] F. Scheinmann, An Introduction to Spectroscopic Methods for the Identification of Organic Compounds, Pergamon, An introduction to spectroscopic methods for the identification of organic compounds, 1970, p. 212.

[33] A.J. Choudhury, J. Chutia, H. Kakati, S.A. Barve, A.R. Pal, N.S. Sarma, et al., Studies of radiofrequency plasma deposition of hexamethyldisiloxane films and their thermal stability and corrosion resistance behavior, Vacuum 84 (2010) 1327-1333.

[34] F. Fracassi, R. d'Agostino, F. Palumbo, E. Angelini, S. Grassini, F. Rosalbino, Application of plasma deposited organosilicon thin films for the corrosion protection of metals, Surf. Coat. Technol. 174 (2003) 107-111.

[35] R.P. Gandhiraman, S.K. Karkari, S.M. Daniels, B. McCraith, Influence of ion bombardment on the surface functionalization of plasma deposited coatings, Surf. Coat. Technol. 203 (2009) 3521-3526.

[36] N.C.D. Cruz, S.F. Durrant, M.A.B.D. Moraes, Thin film deposition from plasmas of tetramethylsilane-helium-argon mixtures with oxygen and with nitrogen, J. Polym. Sci. B Polym. Phys. 36 (1998) 1873-1879.

[37] M. Ricci, J.L. Dorier, C. Hollenstein, P. Fayet, Influence of argon and nitrogen admixture in HMDSO/O-2 plasmas onto powder formation, Plasma Process. Polym. 8 (2011) 108-117.

[38] C.M. Bollen, P. Lambrechts, M. Quirynen, Comparison of surface roughness of oral hard materials to the threshold surface roughness for bacterial plaque retention: a review of the literature, Dent. Mater. 13 (1997) 258-269.

[39] F. Aykent, I. Yondem, A.G. Ozyesil, S.K. Gunal, M.C. Avunduk, S. Ozkan, Effect of different finishing techniques for restorative materials on surface roughness and bacterial adhesion, J. Prosthet. Dent. 103 (2010) 221-227.

[40] W. Teughels, N. Van Assche, I. Sliepen, M. Quirynen, Effect of material characteristics and/or surface topography on biofilm development, Clin. Oral Implants Res. 17 (2006) 68-81.

[41] S. Hahnel, M. Rosentritt, G. Handel, R. Burgers, Surface characterization of dental ceramics and initial streptococcal adhesion in vitro, Dent. Mater. 25 (2009) 969-975.

[42] R. Hickel, A. Peschke, M. Tyas, I. Mjör, S. Bayne, M. Peters, et al., FDI World Dental Federation: clinical criteria for the evaluation of direct and indirect restorations-update and clinical examples, Clin Oral Investig 14 (2010) 349-366.

[43] S.A. Yannikakis, A.J. Zissis, G.L. Polyzois, C. Caroni, Color stability of provisional resin restorative materials, J. Prosthet. Dent. 80 (1998) 533-539.

[44] L. Zajíčková, V. Buršíková, V. Peřina, A. Macková, D. Subedi, J. Janča, et al., Plasma modification of polycarbonates, Surf. Coat. Technol. 142 (2001) 449-454.

[45] W.M. Johnston, E.C. Kao, Assessment of appearance match by visual observation and clinical colorimetry, J. Dent. Res. 68 (1989) 819-822.

[46] J.C. Ragain, W.M. Johnston, Minimum color differences for discriminating mis match between composite and tooth color, J. Esthet. Restor. Dent. 13 (2001) 41-48.

[47] A. Vichi, M. Ferrari, C.L. Davidson, Color and opacity variations in three different resin-based composite products after water aging, Dent. Mater. 20 (2004) 530-534.

[48] N. Alghazali, G. Burnside, M. Moallem, P. Smith, A. Preston, F.D. Jarad, Assessment of perceptibility and acceptability of color difference of denture teeth, J. Dent. 40 (2012) e10-e7.

[49] G.J. Wan, P. Yang, R.K.Y. Fu, Y.F. Mei, T. Qiu, S.C.H. Kwok, et al., Characteristics and surface energy of silicon-doped diamond-like carbon films fabricated by plasma immersion ion implantation and deposition, Diam. Relat. Mater. 15 (2006) 1276-1281.

[50] D.S. Wavhal, J. Zhang, M.L. Steen, E.R. Fisher, Investigation of gas phase species and deposition of $\mathrm{SiO}_{2}$ films from $\mathrm{HMDSO} / \mathrm{O}_{2}$ plasmas, Plasma Process. Polym. 3 (2006) 276-287.

[51] R. D'Agostino, Plasma Deposition, Treatment and Etching of Polymers, Academic Press, INC, San Diego, California, 1990.

[52] R.G. Turri, R.M. Santos, E.C. Rangel, N.C. da Cruz, J.R.R. Bortoleto, J.H.D. da Silva, et al., Optical, mechanical and surface properties of amorphous carbonaceous thin films obtained by plasma enhanced chemical vapor deposition and plasma immersion ion implantation and deposition, Appl. Surf. Sci. 280 (2013) 474-481.

[53] A. Anders, Handbook of Plasma Immersion Ion Implantation and Deposition, Wiley, 2000.

[54] E.C. Rangel, N.C. da Cruz, R.C.C. Rangel, R. Landers, S.F. Durrant, Effect of ion irradiation on the structural properties and hardness of a-C:H:Si:O:F films, J. Phys. Conf. Ser. 591 (2015).

[55] S.M.A. Guruvenketa, D. Lib, J.A. Szpunarb, L. Martinua, J.E. Klemberg-Sapiehaa, Structural, mechanical, tribological, and corrosion properties of a-SiC:H coatings prepared by PECVD, Surf. Coat. Technol. 204 (2010) 3358-3365.

[56] R. Morent, N. De Geyter, S. Van Vlierberghe, P. Dubruel, C. Leys, E. Schacht, Organic-inorganic behaviour of HMDSO films plasma-polymerized at atmospheric pressure, Surf. Coat. Technol. 203 (2009) 1366-1372.

[57] F. Benítez, E. Martínez, J. Esteve, Improvement of hardness in plasma polymerized hexamethyldisiloxane coatings by silica-like surface modification, Thin Solid Films 377 (2000) 109-114.

[58] S. Gallis, V. Nikas, A.E. Kaloyeros, Silicon oxycarbide thin films and nanostructures: synthesis, properties and applications, in: N.N. Nikitenkov (Ed.), Modern Technologies for Creating the Thin-film Systems and Coatings, InTech, Rijeka, 2017(p. Ch. 14).

[59] J.-C. Durand, B. Jacquot, H. Salehi, M. Fages, J. Margerit, F.J.G. Cuisinier, Confocal Raman microscopic analysis of the zirconia/feldspathic ceramic interface, Dent. Mater. 28 (2012) 661-671.

[60] F. Shojai, A. Pettersson, T.A. Mäntylä, J. Rosenholm, Detection of carbon residue on the surface of $3 \mathrm{Y}-\mathrm{ZrO}_{2}$ powder and its effect on the rheology of the slip, Ceram. Int. 26 (2000) 133-139.

[61] S. Masia, P.D. Calvert, W.E. Rhine, H.K. Bowen, Effect of oxides on binder burnout during ceramics processing, J. Mater. Sci. 24 (1989) 1907-1912.

[62] T. Hooshmand, R. Daw, R. van Noort, R.D. Short, XPS analysis of the surface of leucite-reinforced feldspathic ceramics, Dent. Mater. 17 (2001) 1-6.

[63] Y. Chaiyabutr, S. McGowan, K.M. Phillips, J.C. Kois, R.A. Giordano, The effect of hydrofluoric acid surface treatment and bond strength of a zirconia veneering ceramic, J. Prosthet. Dent. 100 (2008) 194-202.

[64] J.-C. Durand, B. Jacquot, H. Salehi, J. Margerit, F.J.G. Cuisinier, Confocal Raman microscopy and SEM/EDS investigations of the interface between the zirconia core and veneering ceramic: the influence of a liner and regeneration firing, J. Mater. Sci. Mater. Med. 23 (2012) 1343-1353.

[65] VITAVM ${ }^{\oplus 9}$ Product Information. 07/2017 ed, VITA Zahnfabrik H. Rauter GmbH \& Co.KG, Spitalgasse 3, D-79713 Bad Säckingen, Germany, 2017, p. 12.

[66] B.T.W. Leung, J.K.H. Tsoi, J.P. Matinlinna, E.H.N. Pow, Comparison of mechanical properties of three machinable ceramics with an experimental fluorophlogopite glass ceramic, J. Prosthet. Dent. 114 (2015) 440-446.

[67] C. Grenade, M.-C. De Pauw-Gillet, P. Gailly, A. Vanheusden, A. Mainjot, Biocompatibility of polymer-infiltrated-ceramic-network (PICN) materials with human gingival fibroblasts (HGFs), Dent. Mater. 32 (2016) 1152-1164.

[68] J.H. Park, Y.S. Choi, Microtensile bond strength and micromorphologic analysis of surface-treated resin nanoceramics, J. Adv. Prosthodont. 8 (2016) 275-284.

[69] R. Belli, M. Wendler, D. de Ligny, M.R. Cicconi, A. Petschelt, H. Peterlik, et al., Chairside CAD/CAM materials. Part 1: measurement of elastic constants and microstructural characterization, Dent. Mater. 33 (2017) 84-98.

[70] N.E. Blanchard, B. Hanselmann, J. Drosten, M. Heuberger, D. Hegemann, Densification and hydration of HMDSO plasma polymers, Plasma Process. Polym. 12 (2015) 32-41.

[71] A. Montarsolo, R. Mossotti, R. Innocenti, E. Vassallo, A study on washing resistance of pp-HMDSO films deposited on wool fabrics for anti-pilling purposes, Surf. Coat. Technol. 224 (2013) 109-113.

[72] N.M. Santos, T.M. Goncalves, J. de Amorim, C.M.A. Freire, J.R.R. Bortoleto, S.F. Durrant, et al., Effect of the plasma excitation power on the properties of SiOxCyHz films deposited on AISI 304 steel, Surf. Coat. Technol. 311 (2017) $127-137$.

[73] M.R. Alexander, F.R. Jones, R.D. Short, Radio-frequency hexamethyldisiloxane plasma deposition: a comparison of plasma- and deposit-chemistry, Plasmas Polym. 2 (1997) 277-300.

[74] J.F. Martinatti, L.V. Santos, N.C. Cruz, E.C. Rangel, Hydrogenated amorphous carbon as protective coating for a forming tool, Eur. Phys. J. Appl. Phys. 56 (2011) 24014.

[75] J.F. Martinatti, L.V. Santos, S.F. Durrant, N.C. Cruz, E.C. Rangel, Lubricating coating prepared by PIIID on a forming tool, 14th Latin American Workshop on Plasma Physics (Lawpp 2011), 2012, p. 370.

[76] J.F. Martinatti, Efeito protetivo produzido pela aplicação de um filme de carbono amorfo na superfície de um ferramental para conformação, Brasil Universidade Estadual Paulista (UNESP), Sorocaba, São Paulo, 2011. 